\title{
Relevance of Educational Philosophy of Rabindranath Tagore in
}

\section{Modern India}

\author{
Nisha Goswami $^{1 *}$, D. S. Malviya ${ }^{2}$
}

\section{ABSTRACT}

Rabindranath Tagore was a great philosopher, thinker, educationist, social activist and intellectual of 20th century. Tagore was a charismatic figure who had a rare great personality, exhibited multidimensional ideas and which has relevance in present era too. It represents important social and cultural changes of the present and rejects claims of classical social thinkers. He establishes a highly pluralistic and diverse view about the education.

Keywords: Education, Rabindranath Tagore, Modern India, Philosophy.

Rabindranath Tagore was a great philosopher, visionary, social reformer, great preacher of Indian culture and tradition. A multidimensional personality endowed with versatile genius and untiring zeal. The contributions of Tagore on Indian education was immense. His ideas reflect a blending of East and West. His ideas and philosophical thoughts were ingrained by the Vedas and Upanishadas on one hand and advocacy for the science of learning, conserving environment and art of creativity on other hand. Tagore opined that the contradictions of human life provoke the quest for the truth. He firmly believed that every human has great soul having sufficient potential to progress towards super human being in the universal soul that can be achieved only through education. According to him, the basic aim of education is to facilitate the individuals to accomplish means of self-realization. The education system of a nation should be able to provide opportunity of all round development to all people of the nation with equal emphasis of acquisition of knowledge and skills.

\section{Concept of education}

According to Tagore (1931) every individual surrounded by education which provide the path of knowledge and cultural link with wider world. The higher education should disseminate information capable of making our existence harmonious. However, it was witnessed that the

\footnotetext{
${ }^{1}$ Research Scholar, Department of Education, R. D. University, Jabalpur, Madhya Pradesh, India

${ }^{2}$ Professor (Retired), Department of Education, P. S. M. College, R. D. University, Jabalpur, Madhya Pradesh, India *Responding Author

(C) 2016, N Goswami, D Malviya; licensee IJIP. This is an Open Access Research distributed under the terms of the Creative Commons Attribution License (http://creativecommons.org/licenses/by/2.0), which permits unrestricted use, distribution, and reproduction in any Medium, provided the original work is properly cited.
} 


\section{Relevance of Educational Philosophy of Rabindranath Tagore in Modern India}

education was systematically ignored in schools and severely repressed. It is pathetic that whatever we learn since childhood in our life, it accentuates from our very nature and our mind as well consequent up on which the world are set in opposition culminating that sort of education we had is neglected and we are made to lose our world to find bag full of information. Thus, it kills hunger of child for epic, because it was supplied with chronological facts and figures. This state of affairs compels the child to assign higher value to protest acting as a calamity ensuing power of suffering subdued at last into science by punishment.

\section{Education Philosophy of Tagore}

The themes inherent in Tagore's philosophy of education has sufficient and unavoidable relevance for present world which is characterized by contradictions and chaos in all walks of life. The contributions made by Tagore was understood by people in order to learn and develop relations not only with ourselves but also in relation to other nations, their religion and culture with special reference to nature. According, to Tagore, life is incessantly creating and to live in creativity is an art. His contributions are scattered from art, literature, music, painting, philosophy to education and social constructions. Through his experiences, Tagore tried to convey his learning to the contemporary generation and made relevant to the future generations. As a social and educational reformer, he initiated to establish institutions like Vishwa Bharati and Shantiniketan as an effective models of new education system.

\section{Education in Independent India}

The existence of crisis that was in the minds of the students drew attention of Rabindranath Tagore. He found that an authoritative system of education has been creating fear in the delicate minds of children. Rabindranath Tagore's focus of educational thoughts were not limited to job creation but it attempted to play a facilitative role in overall development of humanity. He wanted schools to be more live and enjoyable. He furnished equal importance to spiritual and scientific knowledge. Rabindranath Tagore was against pouring of information into the mind of learners.

Tagore believed that education should be open for all that believed in globalization of education. The globalization of education broadens one's mind and induce more tolerance to differences created by boundaries of one's home, culture and nation. According to Tagore, nation is like a family and for families constituting society, the members should be educated for which we have to eradicate illiteracy and inculcate skills. He advocated skilled based learning in the curriculum.

Being a social reformer, Rabindranath Tagore advocated educational tool for social change by turning young people into independent and creative thinkers rather than blind followers of rituals and traditions. Burden of memory is our obstacle in the flow of learning. Understanding enables learning to deepen and consolidate as well as open itself to creative experimentation. Thoughts 


\section{Relevance of Educational Philosophy of Rabindranath Tagore in Modern India}

and actions can integrate continuously leading to newer ways of thinking the bridging at once the past with the present future.

Rabindranath Tagore emphasized freedom of the child which is essential for learning and acquisition of skills and knowledge. A child should be fearless in expression. He had three aims for the students: (1) Enrich literature and other arts to reform education and develop village. (2) to develop capability to think in terms of entire mankind. (3) to enable the students which empowers them to go beyond limitations of their animal nature and to complete the journey of humanism.

Tagore views on spirituality was like that 'God is Satyam, truth.' 'He is ananda rupam amritam' water, earth and sky have imposed bindings on us in many ways and of various sorts. But the ground festival of myriad beauty that is held by the varied colours fragrances, and music within water- air sky do not force itself upon as is the least.

\section{Relevance of Education Philosophy of Tagore in Modern India}

Educational policy having coherence with the demands and needs of the immediate sociocultural milieu of the people should have benefitting effects for all members of society. Education in relation to minds of the individuals is not just a formal system rather it should be an attitude of teaching and learning in a spirit of sharing with strong departure from give and take like material things.

The existing crisis which is in the minds of the learners at present is calling for an educational system, in which new thoughts and ideas can be poured entailing realities of life. To establish coherence with the changing environmental, social and political scenario, the educational principles of Tagore have great relevance and implications. The unity of West and East, natural growth in natural circumstances, Discard book-centered education, Independence of the learner, adoption of real and practical teaching, place of fine arts, educational for rural reconstruction are some examples.

\section{CONCLUSIONS}

Education is continuous process of learning and the existence of present is always in shoulder of past and ultimately from present it will be passed on to the future. Thus, it is concluded that the teaching and methodologies of Tagore are still have relevance and great applicability in the present era of education system being practiced in our country and even around the globe. Establishing educational institutions amidst nature is instrumental in bringing about change in the leaning atmosphere which may play significant role in developing creative mind and facilitate nation building with highest harmony, productivity, happiness and flourishing of all kind in the citizens of the great Indian nation that has a great repository of knowledge, philosophy, traditions of teaching and learning without harming nature and their cohabitants. 


\section{IMPLICATIONS}

The present article attempted to explicate the main themes of educational and philosophical contributions of Gurudev Rabindranath Tagore, his concept of humanism that can be cultivated through education with emphasis that the systems advocated by him have solutions to modern day educational problems of India as well as the whole world. The eclectic understanding of Tagore's philosophy has great relevance for the academicians, administrators, policy makers, researchers and policy makers who can use these principles for the building of nation, brotherhood, reduce unemployment and discrimination in educational and other opportunities being practiced even in the face of a vibrant Indian Constitution and legal system.

\section{Acknowledgement}

This piece of work could not have been materilized to its present form without the help extended by Professor Deepak Vyas, Department of Botany, School of Biological sciences, Dr. H. S. Gour University, Sagar, M. P., India. Dr. G. K. Tiwari, Assistant Professor of Psychology of the same institution also contributed in preparing the manuscripts and helped in proof reading.

\section{REFERENCES}

Guha, M. (2013). Education in Tagorean Perspective, International Journal of Humanities and Social Science Invention, pp. 35-41.

Islam, A. \& Pandey, D. (2013). Rabindranath Tagore - A Visionary : It is ideas on education and rural reconstruction. An international peer reviewed scholarly research journal for interdisciplinary studies, pp.472-485.

Pushpanathan, T. (2013). Rabindranath Tagore's philosophy of education and its influence on Indian education. International Journal of Current Research and Academic Review, pp.42-45.

Sharma, R. N. (2002). Text Book of Educational Philosophy, New Delhi, Kanishka Publishers, p.320.

Tagore, R. (1931). My Educational Mission in the Modern Review, p.621-3.

How to cite this article: N Goswami, S Malviya (2016), Relevance of Educational Philosophy of Rabindranath Tagore in Modern India, International Journal of Indian Psychology, Volume 3, Issue 4, No. 60, ISSN 2348-5396 (e), ISSN: 2349-3429 (p), DIP: 18.01.107/20160304, ISBN: 978-1-365-26308-8 